\title{
STUDI KOMPARASI PENURUNAN KESADAHAN MENGGUNAKAN SERBUK ECENG GONDOK TERAKTIVASI ASAM DAN BASA DENGAN SISTEM KANTONG CELUP
}

\author{
Nisa Nurhidayanti ${ }^{1)}$, Supriyanto ${ }^{2)}$, Yuli Winarto ${ }^{3)}$ \\ ${ }^{1,2,3)}$ Fakultas Teknik, Universitas Pelita Bangsa, Bekasi \\ E-mail : nisa.kimia@pelitabangsa.ac.id
}

\begin{abstract}
Abstrak
Air sumur di Komplek PJKA RT 01 / RW 01 Dusun Tanjungsari Lemah Abang Cikarang Utara memiliki kesadahan yang tinggi. Kesadahan air sumur yang tinggi apabila dikonsumsi dapat membahayakan kesehatan manusia, terutama bagi fungsi ginjal sebagai organ ekskresi. Eceng gondok merupakan salah satu jenis tumbuhan air yang mempunyai kemampuan menyerap polutan pencemaran air, salah satunya adalah kesadahan air. Konsumsi air sadah dalam jangka waktu yang lama dapat menimbulkan gangguan fungsi ginjal. Penelitian ini bertujuan untuk mengetahui kefektifan adsorben eceng gondok teraktivasi $\mathrm{HCl} 3 \mathrm{M}$ dan $\mathrm{NaOH} 2 \%$ dengan variasi massa dalam menurunkan kadar kesadahan air sumur gali. Penelitian ini merupakan penelitian eksperimental dengan desain penelitian uji pendahuluan untuk mengetahui kadar kesadahan awal kemudian dikontakkan dengan serbuk eceng gondok teraktivasi. Hasil penelitian menunjukkan bahwa adsorben eceng gondok teraktivasi $\mathrm{HCl} 3 \mathrm{M}$ dengan variasi dosis 0,5 g mampu mengapsorpsi kesadahan sebesar 11,15\% dengan nilai kesadahan teradsorpsi sebesar $62,5 \mathrm{mg} / \mathrm{L}$ dan nilai kesadahan menjadi $498 \mathrm{mg} / \mathrm{L}$. Sedangkan adsorben eceng gondok teraktivasi $\mathrm{NaOH} 2 \%$ dengan variasi dosis $0,1 \mathrm{~g}$ mampu mengapsorpsi kesadahan sebesar $34,5 \mathrm{mg} / \mathrm{l}$ atau dengan persen adsorpsi sebesar 6,16\% dan nilai kesadahan menjadi $526 \mathrm{mg} / \mathrm{L}$.
\end{abstract}

Kata kunci : asam, basa, eceng gondok, kantong celup, komparasi

\begin{abstract}
The well water in the PJKA Complex RT 01 / RW 01 Dusun Tanjungsari Lemah Abang North Cikarang has high hardness. High hardness of well water when consumed can endanger human health, especially for kidney function as an excretory organ. Water hyacinth is one type of aquatic plant that has the ability to absorb water pollution pollutants, one of which is water hardness. Consumption of hard water in the long term can cause impaired kidney function. This study aims to determine the effectiveness of activated water hyacinth adsorbents $3 \mathrm{M} \mathrm{HCl}$ and $2 \% \mathrm{NaOH}$ with mass variations in reducing the hardness of dug well water. This research is an experimental study with a preliminary test research design to determine the initial hardness level then contacted with activated water hyacinth powder. The results showed that activated water hyacinth adsorbent $3 \mathrm{M} \mathrm{HCl}$ with a dose variation of $0.5 \mathrm{~g}$ was able to absorb $11.15 \%$ hardness with an adsorbed hardness value of $62.5 \mathrm{mg} / \mathrm{L}$ and a hardness value of $498 \mathrm{mg} / \mathrm{L}$. While the activated water hyacinth adsorbent $\mathrm{NaOH} 2 \%$ with a dose variation of $0.1 \mathrm{~g}$ was able to absorb a hardness of $34.5 \mathrm{mg} / \mathrm{l}$ or with an adsorption percent of $6.16 \%$ and a hardness value of $526 \mathrm{mg} / \mathrm{L}$.
\end{abstract}

Keywords : acid, base, water hyacinth, dip bag, comparison

\section{PENDAHULUAN}

Kesadahan sementara pada air dapat diturunkan dengan metode pemanasan. Pemanasan menggunakan wadah periuk tanah liat yang mengandung batuan silica sebagai satu senyawa yang terkandung dalam zeolit dapat dijadikan pilihan. Salah satu media yang digunakan untuk menurunkan kesadahan yaitu dengan menggunakan media zeolit yang berasal dari mineral 
alumino silica yang terdehidrasi dengan kation alkali dan alkali tanah, dan memiliki struktur dalam tiga dimensi berongga yang tidak terbatas. Variasi perbandingan silica dan aluminium akan menghasilkan banyak jenis mineral zeolit yang terdapat di alam (Maran \& Pare, 2019). Metode proses pengadukan dan adsorbsi dari zeolit juga telah dilakukan untuk menurunkan kesadahan terhadap air sumur warga sekitar Lumpur Lapindo (Lestari dan Ayu, 2017). Penurunan kesadahan juga dapat dilakukan dengan menggunakan metode adsorpsi dengan menggunakan karbon aktif sehingga air tanah dapat digunakan sebagai air baku air minum yang lebih layak untuk dikonsumsi masyarakat (Qonita et al., 2019).

Eceng gondok (Eichornia crassipes) merupakan tumbuhan yang tumbuh dan mengapung di permukaan air karena memiliki daun tebal yang menggelembung (Rorong dan Suryanto, 2010). Eceng gondok berkembang biak dengan sangat pesat sehingga dianggap sebagai tumbuhan yang dapat merusak lingkungan di perairan (Stefhany et al., 2013). Permasalahan yang diakibatkan oleh pesatnya pertumbuhan eceng gondok, terdapat potensi yang perlu dimanfaatkan, salah satunya sebagai penyerap logam berat (Lahenda et al., 2015). Adsorben yang berasal dari biomassa eceng gondok mengandung selulosa, hemiselulosa, dan lignin. Selain itu, adsorben yang berasal dari tanaman eceng gondok mempunyai beberapa gugus fungsi aktif seperti karboksil dan juga hidroksil untuk menjerap ion kalsium $\left(\mathrm{Ca}^{2+}\right)$. Tidak hanya gugus fungsi hidroksil $(\mathrm{OH})$ dan karboksil $(\mathrm{COOH})$ yang dimiliki eceng gondok, tetapi juga gugus fungsi lain seperti amina $\left(\mathrm{NH}_{2}\right)$ dan karbonil $(\mathrm{COH})$ (Rakhmania et al., 2017). Tanaman ini juga dapat dimanfaatkan untuk mengurangi pencemaran kadar logam berat pada air yang tercemar $\mathrm{Pb}, \mathrm{Cd}, \mathrm{Cu}, \mathrm{Fe}, \mathrm{Zn}$, dan $\mathrm{Hg}$, karena eceng gondok merupakan tanaman yang tanaman dengan toleransi tinggi yang dapat tumbuh di dalam limbah dengan baik mampu tumbuh dengan cepat serta dapat mengakumulasi juga menyerap logam dalam waktu yang singkat dengan baik (Rahayu et al., 2014).

Penelitian Nahrun (2016) menyatakan bahwa serbuk eceng gondok (Eichornia crassipes) yang telah diaktivasi menggunakan larutan $\mathrm{NaOH} 2 \%$ dapat mengadsorpsi logam timbal $(\mathrm{Pb})$ yang berasal dari danau buatan Universitas Hasanuddin Makassar. Kondisi optimum penurunan logam timbal diperoleh menggunakan massa adsorben enceng gondok sebesar 800 mg dengan variasi waktu pengadukan selama 60 menit menjadi 7,403 ppm. Sedangkan penelitian yang dilakukan oleh Miftahurrahmah et al (2017), adsorben serbuk eceng gondok teraktivasi $\mathrm{NaOH}$ mampu menurunkan ion logam merkuri sebesar 99,79\%. 
Pemanfaatan serbuk eceng gondok teraktivasi sebagai adsorben logam kadmium (Cd) dengan metode kantung celup dilakukan oleh Azhari et al (2017) dengan waktu kontak 30 menit adsorben mampu menjerap logam Cd sebesar 57,175 mg/L atau sebesar 56, $441 \%$ dengan konsentrasi larutan optimum 100 mg/L. Sedangkan Rakhmania, et al (2017), eceng gondok yang sudah diregenerasi menggunakan larutan $\mathrm{HCl}$ dan digunakan untuk adsorben dalam mengadsorpsi ion kalsium. Hasil penelitian menunjukkan bahwa waktu kontak optimum yang didapat adalah 40 menit dengan konsentrasi $\mathrm{HCl} 3 \mathrm{M}$. Dan dengan waktu dan konsentrasi tersebut, adsorben eceng gondok mampu menjerap ion kalsium sebesar $38.733 \mathrm{mg} \mathrm{Ca} / \mathrm{gr}$ adsorben.

Dalam penelitian lain oleh Tudjuka et al (2017), arang enceng gondok mampu menjerap fenol sebesar 4,07 $\mathrm{mg} / \mathrm{L}$ atau dalam presentase sebesar 89,13\% dengan berat arang eceng gondok yang dibutuhkan sebesar $20 \mathrm{mg}$. Sedangkan penelitian pada tahun 2019, Fitriani dan timnya (Fitriani et al., 2019) adsorbsi optimum variasi massa terhadap zat warna Remazol Golden Yellow diperoleh pada massa adsorben 2,5 gram/100 mL dengan efisiensi adsorbsi $74,767 \%$.

Air sumur gali memiliki kualitas yang pada umumnya baik, akan tetapi banyak tergantung kepada sifat lapisan tanahnya. Air sumur gali dihasilkan dari lapisan tanah yang relatif dekat dengan permukaan tanah, sehingga air tersebut mudah terkontaminasi melalui rembesan polutan yang ada di permukaan tanah (Abidin dan Widarto, 2009).

Berdasarkan PERMENKES RI No. 32 Tahun 2017 tentang baku mutu kesehatan lingkungan dan persyaratan kesehatan air, bahwa air untuk kebutuhan higiene dan sanitasi berbeda kualitas dengan air yang digunakan untuk air minum. Kesadahan $\left(\mathrm{CaCO}_{3}\right)$ merupakan salah satu parameter kimia wajib air untuk keperluan higiene sanitasi. Dan jumlah kesadahan dalam air untuk kebutuhan higiene dan juga sanitasi yang diijinkan adalah sebesar $500 \mathrm{mg} / \mathrm{L}$.

Konsumsi air sadah dengan jangka panjang dapat mengakibatkan gangguan kerusakan organ tubuh seperti organ ginjal. Gangguan tersebut terakumulasinya endapan $\mathrm{CaCO}_{3}$ dan $\mathrm{MgCO}_{3}$. Dan apabila dikonsumsi oleh orang yang mempunyai fungsi ginjal yang kurang baik, akan berpotensi terjadinya batu ginjal (Bujawati et al., 2014).

Air sumur di Komplek PJKA RT 01 / RW 01 Dusun Tanjungsari Lemah Abang Cikarang Utara mengandung kesadahan tinggi. Berdasarkan uji pendahuluan diperoleh hasil kadar kesadahan air rata-rata sebesar 560,5 mg/L. Hal ini menunjukkan kadar kesadahan air sumur 
tidak memenuhi baku mutu, dimana kadar kesadahan air yang diijinkan adalah sebesar 500 $\mathrm{mg} / \mathrm{L}$.

Berdasarkan permasalahan tersebut, dilakukan penelitian terkait penurunan kesadahan air sumur gali dengan metode aktivasi asam dan basa dengan adsorben serbuk eceng gondok dan mengemasnya dalam kantong celup. Kebaruan dari penelitian ini adalah membandingkan hasil antara penggunaaan metode aktivasi asam dan basa dengan adsorben serbuk enceng gondok dengan pengemasan kantong celup untuk mempermudah pemisahan adsorben yang digunakan.

\section{METODE PENELITIAN}

Penelitian ini merupakan penelitian eksperimental. Uji pendahuluan dilakukan untuk mengetahui kadar kesadahan sesuai dengan baku mutu Peraturan Menteri Kesehatan No. 32 Tahun 2017 pada sampel air sumur gali dengan metode Titrimetri dengan acuan SNI 066989.12-2004.

\subsection{Bahan Penelitian}

Bahan-bahan yang digunakan dalam pnelitian ini adalah air sumur gali komplek PJKA, daun eceng gondok, $\mathrm{HCl}$ 37\% MERCK Pro Analyst, aquadest, kantong celup, indikator mureksid pro analyst, indikator $\mathrm{EBT}, \mathrm{NH}_{4} \mathrm{Cl}, \mathrm{NH}_{4} \mathrm{OH}, \mathrm{MgEDTA}, \mathrm{CaCO}_{3}$, indikator methyl red, $\mathrm{Na}_{2}$ EDTA, NaCl, NaOH 99\% MERCK Pro Analyst, KCN dan kertas saring whatman.

\subsection{Alat Penelitian}

Alat-alat yang digunakan dalam penelitian ini adalah neraca analitik, ayakan 50 dan 100 mesh, lemari asam, oven, tray dryer, chopper, shaker, stopwatch, buret, labu erlenmeyer, labu ukur, gelas ukur, gelas piala, pipet volume, corong kaca, alat pengukur $\mathrm{pH}$ dan pengaduk gelas.

\subsection{Tahapan Penelitian}

\subsubsection{Pengambilan Contoh Uji}

Pengambilan contoh uji air sumur gali di daerah Komplek PJKA RT 01 / RW 01 Dusun Tanjungsari Lemah Abang Cikarang Utara. Pengambilan eceng gondok dari danau buatan di Perumahan Griya Kota Bekasi 2 Tambun Utara Kabupaten Bekasi. 


\subsubsection{Penyiapan Eceng Gondok}

Bagian daun eceng gondok dibersihkan dengan cara dicuci. Kemudian daun yang sudah dibersihkan, dipotong ukuran kecil (kurang dari $1 \mathrm{~cm}^{2}$ ) kemudian dijemur di bawah terik matahari untuk mengurangi kadar air. Untuk mencapai berat kering konstan, daun eceng gondok yang sudah dijemur selanjutnya dikeringkan menggunakan oven drier dengan suhu $105 \pm 2{ }^{\circ} \mathrm{C}$ selama satu jam. Eceng gondok yang sudah mencapai bobot kostan, dihaluskan menggunakan chopper selanjutnya diayak dengan ayakan berukuran 50 mesh.

\subsubsection{Aktivasi Eceng Gondok dengan $\mathrm{HCl}$}

Serbuk eceng gondok kering diaktivasi dengan menggunakan $\mathrm{HCl}$ dengan konsentrasi $3 \mathrm{M}$. Aktivasi dilakukan selama 2 jam dengan perbandingan massa serbuk eceng gondok dan larutan $\mathrm{HCl}$ sebesar $1 \mathrm{~g}$ : $20 \mathrm{~mL}$. Setelah diaktivasi, seluruh serbuk eceng gondok dicuci dengan aquades hingga mencapai $\mathrm{pH}$ mendekati netral. Selanjutnya memisahkan antara residu dan filtratnya menggunakan kertas saring. Kemudian residu dari hasil filtrasi dikeringkan menggunakan oven dengan suhu $105 \pm 2{ }^{\circ} \mathrm{C}$ selama satu jam hingga dicapi bobot konstan.

\subsubsection{Aktivasi Eceng Gondok dengan $\mathrm{NaOH}$}

Serbuk eceng gondok ditimbang $2 \mathrm{~g}$ dan dimasukkan dalam gelas piala yang selanjutnya diaktivasi menggunakan larutan $\mathrm{NaOH} 2 \%$ sebanyak $100 \mathrm{~mL}$ selama 24 jam. Selanjutnya memisahkan antara residu dengan filtratnya menggunakan kertas saring. Kemudian residu dari hasil filtrasi dikeringkan menggunakan oven dengan suhu $105 \pm 2{ }^{\circ} \mathrm{C}$ selama satu jam hingga dicapai bobot konstan.

\subsubsection{Pengemasan dalam Kantong Celup}

Serbuk eceng gondok kering yang sudah diaktivasi ditimbang dengan massa tertentu selanjutnya serbuk eceng gondok dikemas menggunakan kantong teh celup kosong.

\subsubsection{Pengujian Pre-Treatment}

Pengujian pre-treatment dilakukan dengan menguji kadar kesadahan total dalam air uji yang diambil dari sumur gali untuk menentukan konsentrasi kesadahan awal sebelum dilakukan pengolahan dengan serbuk eceng gondok teraktivasi.

\subsubsection{Percobaan Dosis Optimum Eceng Gondok Teraktivasi}

Percobaan ini dilakukan untuk mengetahui dosis serbuk eceng gondok yang paling optimum. Adsorben eceng gondok dengan aktivator asam klorida $(\mathrm{HCl})$ dengan konsentrasi $3 \mathrm{M}$ dan 
natrium hidroksida $(\mathrm{NaOH}) 2 \%$ dimasukkan dalam kantong celup masing masing $0,1 \mathrm{~g} ; 0,2$ g; 0,3 g; 0,4 g dan 0,5 g. Kemudian dilakukan pencelupan pada masing-masing $500 \mathrm{~mL}$ sampel sumur gali dengan waktu kontak 40 menit untuk aktivator $\mathrm{HCl}$ dan 60 menit untuk aktivator $\mathrm{NaOH}$. Kemudian dilakukan pengujian kesadahan pada tiap sampel air tersebut. Dosis optimum merupakan jumlah minimal adsorben dengan hasil pengujian kesadahan yang paling kecil. Artinya dosis adsorben paling minimal namun mampu mengikat kesadahan paling maksimal.

\subsection{Perhitungan}

\subsubsection{Perhitungan Kadar Kalsium dan Magnesium}

Penentuan kadar kalsium dan magnesium di dalam air sampel, menggunakan metode SNI 06-6989.12-2004. Perhitungan kadar kalsium dan magnesium disajikan pada persamaan 1 dan persamaan 2 sebagai berikut (SNI 06-6989.12-2004, 2004) :

Kadar kalsium (mg Ca/L) $\quad=\frac{1000}{V_{\text {contoh uji }}} \times V_{\text {EDTA(b) }} \times M_{\text {EDTA }} \times 40$

$\operatorname{Kadar}$ magnesium $(\mathrm{mg} \mathrm{Mg} / \mathrm{L})=\frac{1000}{\mathrm{~V}_{\text {contoh ưj }}} \times\left[\mathrm{V}_{\mathrm{EDTA}(\mathrm{a})}-\mathrm{V}_{\mathrm{EDTA}(\mathrm{b})]} \times \mathrm{M}_{\mathrm{EDTA}} \times 24,3\right.$

\subsubsection{Perhitungan Kadar Kesadahan Total}

Dalam menentukan kadar kesadahan total dalam air sampel, menggunakan metode APHA 2340B ed 23 - 2017. Dimana jumlah kadar kalsium dan magnesium dijumlahkan untuk mendapatkan kadar kesadahan total. Persamaan perhitungan kadar kesadahan total disajikan pada persamaan 3 sebagai berikut (APHA-2340 Hardness, 2017) :

$$
\text { Kesadahan Total }\left(\mathrm{CaCO}_{3}\right)=2,497[\mathrm{Ca}, \mathrm{mg} / \mathrm{L}]+4,118[\mathrm{Mg}, \mathrm{mg} / \mathrm{L}]
$$

\section{HASIL DAN PEMBAHASAN}

\subsection{Uji Pendahuluan}

Uji pendahuluan dilakukan untuk mengetahui kadar kesadahan yang terkandung pada sampling air sumur di Komplek PJKA RT 01 / RW 01 Dusun Tanjungsari Lemah Abang Cikarang Utara. Hasil uji pendahuluan yang dilakukan pada sampel air sumur Komplek PJKA disajikan pada Tabel 1. 
Tabel 1. Hasil Uji Pendahuluan Kadar Kesadahan Pada Sampel Air Sumur Komplek PJKA

\begin{tabular}{cccc}
\hline \multicolumn{2}{c}{ Kesadahan $(\mathrm{CaCO3}) \mathbf{m g} / \mathrm{L}$} & $\begin{array}{c}\text { Rata-rata } \\
(\mathbf{m g} / \mathbf{L})\end{array}$ & $\begin{array}{c}\text { Standar Baku Mutu } \\
(\mathbf{m g} / \mathrm{L})\end{array}$ \\
\hline Pengujian pertama & Pengujian kedua & 560,5 & 500 \\
\hline 561 & 560 & 5600 \\
\hline
\end{tabular}

Berdasarkan hasil uji pendahuluan yang dilakukan bahwa air sumur di Komplek PJKA RT 01 / RW 01 Dusun Tanjungsari Lemah Abang Cikarang Utara mengandung kesadahan rata-rata sebesar 560,5 mg/l. Hal ini menunjukkan kadar kesadahan air sumur di Komplek PJKA RT 01 / RW 01 Dusun Tanjungsari Lemah Abang Cikarang Utara telah melebihi ambang baku mutu PERMENKES Republik Indonesia No. 32 Tahun 2017. Dimana kadar kesadahan yang diperbolehkan untuk media air dalam keperluan higiene sanitasi tidak lebih dari $500 \mathrm{mg} / \mathrm{L}$.

\subsection{Variasi Dosis Serbuk Gondok Teraktivasi HCl 3M Terhadap Penurunan Kesadahan} Air

Pada tahapan ini, air sampel dikontakkan dengan serbuk eceng gondok teraktivasi $\mathrm{HCl} 3 \mathrm{M}$ yang telah dikemas dalam kantong celup menggunakan variasi dosis $0,1 \mathrm{~g} ; 0,2 \mathrm{~g} ; 0,3 \mathrm{~g} ; 0,4 \mathrm{~g}$ dan 0,5 g selama 40 menit. Hasil pengujian kesadahan sampel air sumur yang dikontakkan dengan eceng gondok teraktivasi dalam variasi dosis asam disajikan pada Tabel 2 sebagai berikut:

Tabel 2. Hasil Uji Kesadahan Pada Sampel Air dengan Serbuk Eceng Gondok Teraktivasi $\mathrm{HCl} 3 \mathrm{M}$ dalam Variasi Dosis

\begin{tabular}{cccccc}
\hline No. & $\begin{array}{c}\text { Dosis Serbuk } \\
\text { Eceng Gondok } \\
(\mathbf{g})\end{array}$ & $\begin{array}{c}\text { Konsentrasi } \\
\text { Awal (a) } \\
(\mathbf{m g} / \mathbf{L})\end{array}$ & $\begin{array}{c}\text { Konsentrasi Sisa } \\
(\mathbf{b}) \\
(\mathbf{m g} / \mathbf{L})\end{array}$ & $\begin{array}{c}\text { Konsentrasi } \\
\text { Teradsorpsi } \\
(\mathbf{a - b}) \\
(\mathbf{m g} / \mathbf{L})\end{array}$ & $\begin{array}{c}\text { Presentase } \\
\text { Teradsorpsi } \\
(\mathbf{\%})\end{array}$ \\
1 & & & & & \\
2 & 0,1 & 560,5 & 547 & 13,5 & 2,41 \\
3 & 0,2 & 560,5 & 541 & 19,5 & 3,48 \\
4 & 0,3 & 560,5 & 525 & 35,5 & 6,33 \\
5 & 0,4 & 560,5 & 514 & 46,5 & 8,30 \\
\hline
\end{tabular}

Pada Tabel 2 menunjukkan bahwa penyerapan kadar kesadahan terbaik terjadi pada dosis 0,5 g serbuk eceng gondok teraktivasi $\mathrm{HCl} 3 \mathrm{M}$ dengan lama pengontakan selama 40 menit. Pada dosis tersebut, persen adsorpsi kesadahan sebesar $11,15 \%$ dengan nilai kesadahan teradsorp sebesar 62,5 mg/l dan nilai kesadahan menjadi $498 \mathrm{mg} / \mathrm{L}$. Itu artinya sudah memenuhi syarat 
baku mutu Peraturan Menteri Kesehatan No.32 Tahun 2017 untuk kesadahan air yaitu sebesar 500 mg/l. Hal ini sesuai dengan penelitian sebelumnya oleh Rakhmania, et al (2017), bahwa adsorben dari biomassa enceng gondok memiliki gugus fungsi hidroksil $(\mathrm{OH})$ dan karboksil $(\mathrm{COOH})$ yang bertindak sebagai gugus fungsi aktif untuk mengadsorpsi ion kalsium. Mekanisme adsorpsi yang terjadi adalah pertukaran ion. Perlakuan aktivasi menggunakan $\mathrm{HCl}$ akan meningkatkan daya adsorpsi ion kalsium. Grafik Penurunan Kadar Kesadahan dengan Aktivator $\mathrm{HCl} 3$ M disajikan pada Gambar 1.

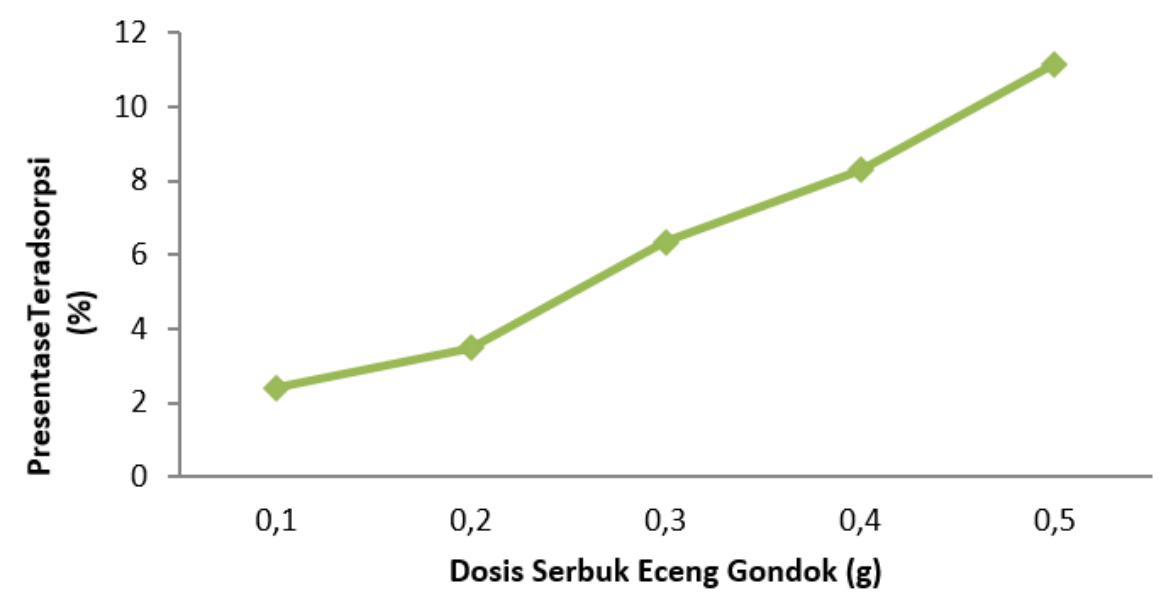

Gambar 1. Grafik Penurunan Kadar Kesadahan dengan Aktivator HCl 3 M

Dari Gambar 1 menujukkan serbuk eceng gondok teraktivasi $\mathrm{HCl} 3 \mathrm{M}$ dengan dosis 0,1 g dan dikontakkan selama 40 menit mampu menurunkan kadar keasadahan sebesar 13,5 mg/L atau 2,41\%, pada dosis 0,2 sebesar 19,5 mg/L dengan persen teradsorpsi 3,48\%, sedangkan pada dosis 0,3 g eceng gondok teraktivasi $\mathrm{HCl} 3 \mathrm{M}$ mampu mengadsorpsi kesadahan sebesar 35,5 $\mathrm{mg} / \mathrm{L}$ atau dengan persen adsorpsi sebesar 6,33\%. Pada dosis 0,4 g, eceng gondok teraktivasi mampu menurunkan kesadahan sebesar 46,5 mg/L atau 8,30\% dan pada dosis $0,5 \mathrm{~g}$, eceng gondok teraktivasi $62,5 \mathrm{mg} / \mathrm{L}$ atau dengan persen teradsorpsi sebesar $11,15 \%$. Hal ini menunjukkan dengan meningkatnya dosis serbuk eceng gondok teraktivasi $\mathrm{HCl} 3 \mathrm{M}$ yang digunakan, semakin meningkat juga kadar kesadahan yang teradsorpsi. Hal ini dikarenakan semakin besar dosis serbuk eceng gondok, maka semakin banyak juga pori-pori yang bekerja dalam menyerap kesadahan dalam air (Nahrun, 2016). Persamaan reaksi antara adsorben eceng gondok teraktivasi dengan kesadahan disajikan dalam Gambar 2 (Azhari et al., 2017). 


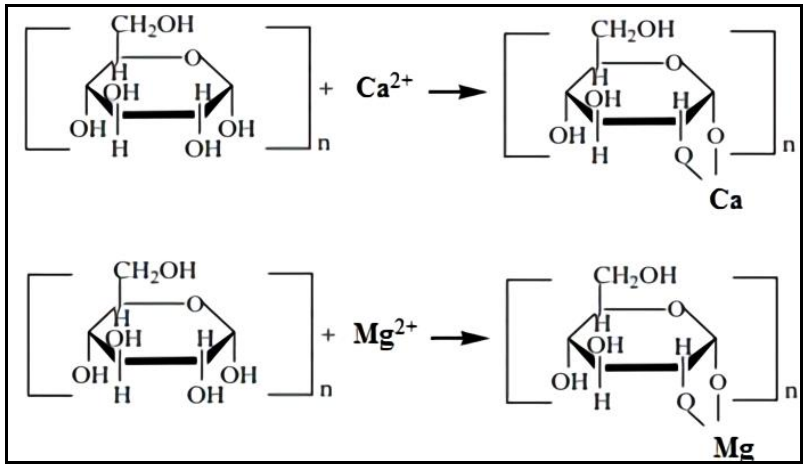

Gambar 2. Raksi antara adsorben eceng gondok teraktivasi dengan kesadahan

Jadi dapat disimpulkan bahwa penyerapan optimum kadar kesadahan oleh eceng gondok teraktivasi $\mathrm{HCl} 3 \mathrm{M}$ dengan massa $0,5 \mathrm{~g}$ dengan nilai adsorpsi sebesar $62,5 \mathrm{mg} / \mathrm{L}$ atau $11,15 \%$.

\subsection{Variasi Dosis Serbuk Eceng Gondok Teraktivasi NaOH 2\% Terhadap Penurunan}

\section{Kesadahan Air}

Pada tahapan ini, eceng gondok yang sudah diaktivasi menggunakan $\mathrm{NaOH} 2 \%$ selama 24 jam dikontakkan dengan sampel air selama 60 menit dalam variasi dosis 0,$1 ; 0,2 ; 0,3 ; 0,4$; dan 0,5. Hasil uji sampel air sumur yang dikontakkan dengan eceng gondok teraktivasi dalam variasi dosis basa disajikan dalam Tabel 3.

Tabel 3. Hasil Uji Kesadahan Pada Sampel Air dengan Serbuk Eceng Gondok Teraktivasi $\mathrm{NaOH} 2 \%$ dalam Variasi Dosis

\begin{tabular}{cccccc}
\hline No. & $\begin{array}{c}\text { Dosis Serbuk } \\
\text { Eceng } \\
\text { Gondok }(\mathbf{g})\end{array}$ & $\begin{array}{c}\text { Konsentrasi } \\
\text { Awal (a) } \\
(\mathbf{m g} / \mathbf{L})\end{array}$ & $\begin{array}{c}\text { Konsentrasi } \\
\text { Sisa (b) } \\
(\mathbf{m g} / \mathbf{L})\end{array}$ & $\begin{array}{c}\text { Konsentrasi } \\
\text { Teradsorpsi } \\
(\mathbf{a}-\mathbf{b})\end{array}$ & $\begin{array}{c}\text { Presentase } \\
\text { Teradsorpsi } \\
(\mathbf{m g} / \mathbf{L})\end{array}$ \\
\hline 1 & 0,1 & 560,5 & 526 & 34,5 & 6,16 \\
2 & 0,2 & 560,5 & 539 & 21,5 & 3,84 \\
3 & 0,3 & 560,5 & 539 & 21,5 & 3,84 \\
4 & 0,4 & 560,5 & 542 & 18,5 & 3,30 \\
5 & 0,5 & 560,5 & 541 & 19,5 & 3,48 \\
\hline
\end{tabular}

Berdasarkan tabel diatas menunjukkan bahwa dosis optimum serbuk eceng gondok teraktivasi $\mathrm{NaOH} 2 \%$ adalah 0,1 g. Dimana adsorben dapat mengardsorpsi kesadahan sebesar 6,16\% dengan nilai kesadahan teradsorpsi sebesar 34,5 mg/L dan kadar kesadahan menjadi $526 \mathrm{mg} / \mathrm{l}$. Hal ini menunjukkan bahwa sebuk eceng gondok yang diaktivasi $\mathrm{NaOH} 2 \%$ selama 24 jam dan dikontakkan selama 60 menit dapat menurunkan kadar kesadahan air. Hal ini 
sesuai dengan penelitian sebelumnya yang dilakukan oleh Nahrun, et al (2016) bahwa serbuk eceng gondok yang diaktivasi $\mathrm{NaOH} 2 \%$ selama 24 jam dengan waktu kontak 60 menit dapat menurunkan kadar ion logam. Grafik Penurunan Kadar Kesadahan dengan Aktivator $\mathrm{NaOH}$ $2 \%$ disajikan pada Gambar 3.

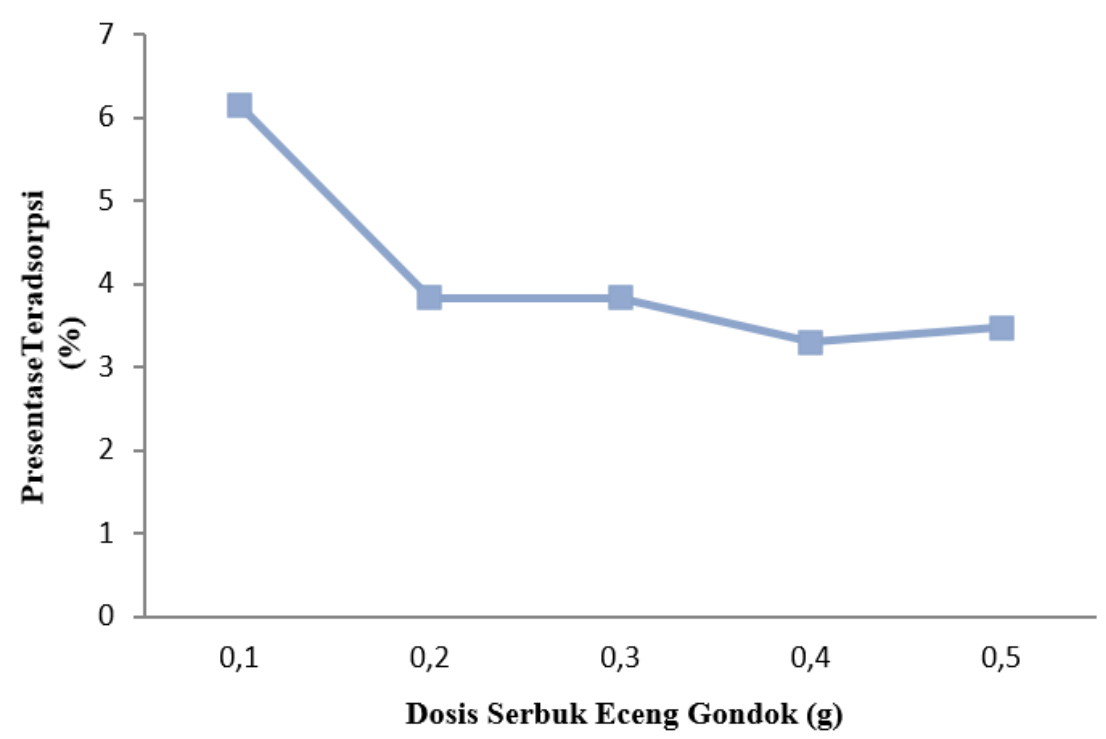

Gambar 3. Grafik Penurunan Kadar Kesadahan dengan Aktivator $\mathrm{NaOH} 2 \%$

Gambar 3 menunjukkan plot grafik daya adsorbsi pada variasi dosis 0,$1 ; 0,2$ g; 0,3;0,4 dan 0,5 dengan aktivator $\mathrm{NaOH} 2 \%$ dan waktu kontak selama 60 menit. Dalam grafik menunjukkan bahwa pada dosis 0,1 g, adsorben mampu mengadsorpsi kesadahan sebesar $34,5 \mathrm{mg} / \mathrm{L}$ atau dengan persen adsorpsi sebesar 6,16\% dan pada dosis 0,2 dan 0,3 g, adsorben sama-sama dapat mengadsorp kadar kesadahan sebesar 21,5 mg/L atau dengan persen adsorpsi sebesar 3,84\%. Sedangkan pada dosis 0,4 g, adsorben dapat mengadsorp kadar kesadahan sebesar 18,5 mg/L atau dengan persen adsorpsi sebesar 3,30\% dan pada dosis 0,5 g, adsorben dapat mengadsorpsi kadar kesadahan sebesar 19,5 mg/L atau dengan persen adsorpsi sebesar 3,48\%. Pada massa 0,2 g sampai dengan 0,4 g, kinerja adsorben cenderung menurun dan pada dosis $0,5 \mathrm{~g}$ kembali naik, tetapi tidak terlalu signifikan hanya $0,18 \%$. Hal tersebut dikarenakan kinerja gugus fungsi hidroksil dan karboksil yang memiliki fungsi sebagai gugus fungsi aktif untuk penjerap kesadahan mulai jenuh oleh ion kalsium dan magnesium.

Hal ini sesuai dengan penelitian Azhari, et al (2017) yang menyatakan bahwa sedikit menurunnya penyerapan oleh adsorben dapat menunjukkan bahwa kinerja senyawa atau gugus yang menjerap ion logam sudah mulai menurun yang disebabkan oleh jenuhnya permukaan pada adsorben oleh ion logam yang terjerap.. Jadi dapat dikatakan bahwa 
konsentrasi optimum kadar kesadahan yang terserap oleh adsorben eceng gondok teraktivasi $\mathrm{NaOH} 2 \%$ yaitu pada massa $0,1 \mathrm{~g}$ dengan nilai adsorpsi sebesar $34,5 \mathrm{mg} / \mathrm{L}$ atau $6,16 \%$.

\section{KESIMPULAN}

Berdasarkan hasil yang diperoleh dari penelitian terhadap kesadahan air sumur ini, dapat ditarik kesimpulan bahwa dosis optimum eceng gondok teraktivasi asam klorida $(\mathrm{HCl})$ untuk menurunkan kesadahan pada air sumur gali adalah sebesar 0,5 g sedangkan dosis optimum eceng gondok teraktivasi natrium hidroksida $(\mathrm{NaOH})$ untuk menurunkan kesadahan pada air sumur gali adalah sebesar $0,1 \mathrm{~g}$. Untuk nilai efektifitas eceng gondok teraktivasi asam klorida $(\mathrm{HCl})$ yang dikemas dalam kantong celup untuk menyerap kesadahan air sumur gali dengan tingkat penurunan sebesar $11,15 \%$ sedangkan nilai efektivitas eceng gondok teraktivasi natrium hidroksida $(\mathrm{NaOH})$ yang dikemas dalam kantong celup untuk menyerap kesadahan air sumur gali dengan tingkat penurunan sebesar $6,16 \%$.

\section{DAFTAR PUSTAKA}

Abidin, Z., dan Widarto, D. (2009). Analisis Kandungan Brom (Br) pada Air Sumur Gali di Desa Klampok Kabupaten Brebes Jawa Tengah dengan Metode Analisis Pengaktifan Neutron. Seminar Nasional V SDM Teknologi Nuklir, 723-730.

APHA-2340: Hardness. (2017). Standart Methods For the Examination of Water and Wastewater.

Azhari, M. R., Saleh, C., dan Yusuf, B. (2017). Pemanfaatan Serbuk Eceng Gondok (Eichornia Crassipes) Teraktivasi dengan Sistem Kantong Celup sebagai Adsorben Penjerap Ion Logam Kadmium (Cd). Jurnal Atomik, 02(2), 197-203.

Bujawati, E., Rusmin, M., dan Basri, S. (2014). Pengaruh Ketebalan Arang Tempurung Kelapa Terhadap Tingkat Kesadahan Air di Wilayah Kerja Puskesmas Sudu Kabupaten Enrekang Tahun 2013. Jurnal Kesehatan, 7(1), 332-345.

Fitriani, I. N., Puspitasari, A. R., dan Amelia, R. N. (2019). Dekolorisasi Senyawa Azo Limbah Remazol Golden Yellow oleh Bioadsorben Eceng Gondok (Eichhornia Crassipes). Journal of Chemistry, 2(2), 40-46.

Lahenda, S. S., Ellyke, dan Khoiron. (2015). Pemanfaatan Eceng Gondok Terhadap Penurunan Kadar Merkuri (Hg) Limbah Cair pada Pertambangan Emas Tanpa Izin (PETI). Jurnal Pustaka Kesehatan, 3 (2), 356-361.

Lestari dan Ayu, D. (2014). Penurunan Kesadahan Air Sumur di sekitar Lumpur Lapindo Dengan Menggunakan Zeolit. Jurnal Teknik Kimia. 8 (2) .

Maran A.A. dan Pare, B.N. (2019). Penurunan Kesadahan Pada Air Sumur GaliMelalui 
Proses Pemanasan Menggunakan Wadah Periuk Tanah. Oehonis : The Journal of Environmental Health Research, 3(1), 153-157.

Miftahurrahmah, Suhendrayatna, dan Zaki, M. (2017). Penyisihan Ion Logam Merkuri $\left(\mathrm{Hg}^{2+}\right)$ Menggunakan Adsorben Berbahan Baku Limbah Pertanian dan Gulma Tanaman. Jurnal Teknik Kimia, 6(1), 7-11.

Nahrun, S. (2016). Pemanfaatan Eceng Gondok (Eichornia Crassipes) dalam Menurunkan Kadar Logam Timbal $(\mathrm{Pb})$ dari Danau Buatan Universitas Hasanuddin Makassar. Tugas Akhir. Makassar : Universitas Islam Negeri Alauddin Makassar.

Permenkes. (2017). Peraturan Menteri Kesehatan Republik Indonesia Nomor 32 Tahun 2017 Tentang Standar Baku Mutu Kesehatan Lingkungan dan Persyaratan Kesehatan Air untuk Keperluan Higiene Sanitasi, Kolam Renang, Solus Per Aqua, dan Pemandian Umum.

Qonita, HN., Izah, M., Harahap, NAB., dan Pakpahan, IS. (2019). Pengurangan Kesadahan Ca dan Mg dengan karbon aktif dan pengaruhnya terhadap kelayakan pada air tanah di Dusun Sambirejo, Kelurahan Talakbroto, Kecamatan Simo, Kabupaten Boyolali. Prosiding Seminar Nasional Kebumian Ke-12. Teknik Geologi Fakultas Teknik Universitas Gajah Mada.

Rahayu, S. T., Faradilla, M., Verawati, E. Y., dan Triana, M. (2014). Respon Bioakumulator Eceng Gondok (Eichhornia Crassipes) Terhadap Logam Berat $\mathrm{Pb}$ dan $\mathrm{Cd}$ di Sungai Pegangsaan Dua. Journal of Pharmaceutical Science and Research, 1(1), 9-15.

Rakhmania, C. D., Khaeronnisa, I., Ismuyanto, B., Juliananda, dan Himma, N. F. (2017). Adsorpsi ion kalsium menggunakan biomassa eceng gondok (Eichhornia Crassipes ) diregenerasi HCl. Jurnal Rekayasa Bahan Alam dan Energi Berkelanjutan, 1 (1), 16-24.

Rorong, J. A., \& Suryanto, E. (2010). Analisis Fitokimia Enceng Gondok (Eichhornia Crassipes) dan Efeknya Sebagai Agen Photoreduksi $\mathrm{Fe}^{3+}$. Chemistry Progress, 3(1), 3341.

SNI 06-6989.12-2004. (2004). Air dan Air Limbah - Bagian 12: Cara Uji Kesadahan Total Kalsium (Ca) dan Magnesium ( $\mathrm{Mg}$ ) dengan Metode Titrimetri.

Stefhany, C. A., Sutisna, M., \& Pharmawati, K. (2013). Fitoremediasi Phospat dengan Menggunakan Tumbuhan Eceng Gondok (Eichhornia Crassipes ) pada Limbah Cair Industri Kecil Pencucian Pakaian ( Laundry ). Jurnal Reka Lingkungan, 1(1), 13-23.

Tudjuka, M. D., Walanda, D. K., \& Hamzah, B. (2017). Arang Eceng Gondok (Eichornia Crassipes) sebagai Adsorben Fenol pada Limbah PLTU Palu. Jurnal Akademia Kimia, 6 (2), 119-124. 